\title{
Requirement of the Escherichia coli dnaK gene for thermotolerance and protection against $\mathrm{H}_{2} \mathrm{O}_{2}$
}

\author{
JOHN M. DELANEY $\dagger$ \\ Department of Microbiology and Immunology, College of Medicine, University of Arizona, Tucson, Arizona 85724, USA
}

(Received 6 February 1990; revised 1 June 1990; accepted 3 July 1990)

Thermotolerance in Escherichia coli is induced by exposing cells to a brief heat shock $\left(42{ }^{\circ} \mathrm{C}\right.$ for 15 min). This
results in resistance to the lethal effect of exposure to a higher temperature $\left(50{ }^{\circ} \mathrm{C}\right)$. Mutants defective in the rec $A$,
$u v r A$ and $x t h A$ genes are more sensitive to heat than the wild-type. However, after development of thermotolerance
these mutants are like the wild-type in their heat sensitivity. This suggests that thermotolerance is an inducible
response capable of protecting cells from the lethal effects of heat, independently of rec $A, u v r A$ and $x t h A$.
Thermotolerance does not develop in a dnaK mutant. In addition, the dnaK mutant is sensitive to heat and $\mathrm{H}_{2} \mathrm{O}_{2}$,
but is resistant to UV irradiation. This implies that the $E$. coli heat-shock response includes a mechanism that
protects cells from heat and $\mathrm{H}_{2} \mathrm{O}_{2}$, but not from UV.

\section{Introduction}

The heat-shock response is a highly conserved genetic response to environmental stress. This response is ubiquitous in nature, having been found in every organism studied for its presence, from bacteria to man (Lindquist, 1986; Neidhardt et al., 1984; Schlesinger et al., 1982). Induction of the heat-shock response in Escherichia coli involves the expression of at least 17 genes, and is caused by stimuli such as $\mathrm{H}_{2} \mathrm{O}_{2}$ treatment, ethanol, UV irradiation and viral infection (Neidhardt $e t$ al., 1984), in addition to heat. Whilst the heat-shock response has been studied extensively, its function is essentially unknown.

When $E$. coli is exposed to a brief, sub-lethal dose of heat it becomes more resistant to subsequent, potentially lethal heat exposure. This phenomenon is termed thermotolerance and has been observed in many organisms (Lindquist, 1986). Interestingly, thermotolerance in $E$. coli does not develop simply through induction of the heat-shock regulon (VanBogelen et al., 1987); however, there are many data which imply that the development of thermotolerance depends upon the heat-shock response. For example, E. coli htpR mutants, in which heat-shock gene expression is blocked, fail to exhibit thermotolerance (Yamamori \& Yura, 1982). Agents other than heat, such as ethanol, which induce the heat-shock

† Present address: Department of Cellular, Viral and Molecular Biology, University of Utah, School of Medicine, Salt Lake City, Utah 84132, USA. response also induce thermotolerance (Lindquist, 1986). In mammalian cells, the accumulation of heat-shock proteins is directly related to the degree to which thermotolerance is expressed (Subjeck \& Sciandra, 1982). Of all heat-shock proteins, the concentration of the $70 \mathrm{kDa}$ heat-shock protein, Hsp70, best correlates with the development of thermotolerance (Lindquist, 1986).

Many inducers of the heat-shock response in E. coli, particularly heat, $\mathrm{H}_{2} \mathrm{O}_{2}$ and UV, are DNA-damaging agents (Ananthaswamy \& Eisenstark, 1977; Bridges et al., 1969a; Massie et al., 1972; Neidhardt et al., 1984; Woodcock \& Grigg, 1972). This finding suggests that a function of the heat-shock response, and/or thermotolerance, may be to protect against the lethal effects of certain environmental agents known to cause DNA damage. To address this idea, the inactivating effect of heat, $\mathrm{H}_{2} \mathrm{O}_{2}$ and UV on repair-deficient mutants and a $d n a K$ mutant of $E$. coli have been studied. The results indicate that the E. coli dnaK mutant is sensitive to heat and $\mathrm{H}_{2} \mathrm{O}_{2}$ but not to $\mathrm{UV}$, and suggest that the dnaK gene may be needed to protect $E$. coli from the lethal effects caused by heat and $\mathrm{H}_{2} \mathrm{O}_{2}$.

\section{Methods}

Bacterial strains. All mutant E. coli strains were derived from AB 1157 (Howard-Flanders \& Theriot, 1966), which is designated wild-type. Strains AB2463 (Howard-Flanders \& Theriot, 1966), AB2480 (Howard-Flanders et al., 1969), BW9101 (Demple et al., 1983) and 
GW4813 (Paek \& Walker, 1987) will henceforth be referred to as recA, $\operatorname{rec} A$ uvr $A, x t h A$ and $d n a K$, respectively. The $\operatorname{rec} A$ and $\operatorname{rec} A u v r A$ mutants have missense mutations, whereas the $x t h A$ and $d n a K$ mutants both have deletion mutations.

Heat treatment. Fresh cultures of bacteria were grown overnight at $30{ }^{\circ} \mathrm{C}$ in Hershey's broth (Steinberg \& Edgar, 1962) prior to each experiment. These cultures were diluted into fresh Hershey's broth and incubated with shaking at $30^{\circ} \mathrm{C}$ to a concentration of about $1 \times 10^{8}$ cells $\mathrm{ml}^{-1}$. Culture $(1 \mathrm{ml})$ was then pipetted into each of seven Eppendorf tubes which were placed in a $50^{\circ} \mathrm{C}$ waterbath for the desired time. Time points represent the total time spent at $50^{\circ} \mathrm{C}$, and do not include the time needed for the culture to come up to temperature. This 'come-up' time was measured to be no more than $2 \mathrm{~min}$ in each experiment. At each time of treatment, a tube was withdrawn from the waterbath, and the bacterial suspensions were immediately serially diluted in M-9 salts solution and plated on Hershey's agar plates using the agar overlay method (Adams, 1959). The bacterial suspensions at all time points were diluted in duplicate, except those at the zero dose time point which were diluted in triplicate. Plates were incubated for $36-48 \mathrm{~h}$ at $30^{\circ} \mathrm{C}$. As a precaution against possible light-induced BNA repair, photoreactivation was avoided by maintaining darkened conditions during these experiments and during plate incubation. Survival at any given time of heat treatment was determined as the ratio of colony-forming units (c.f.u.) after treatment to the number of c.f.u. at the zero time point.

Thermotolerance. Thermotolerance experiments were done as described above for heat treatment except that prior to the $50{ }^{\circ} \mathrm{C}$ exposure, the bacterial suspensions ( $1.0 \mathrm{ml}$ in plastic Eppendorf tubes) were placed at $42^{\circ} \mathrm{C}$ for $15 \mathrm{~min}$ (not including 'come-up' time). Following this $42^{\circ} \mathrm{C}$ heat treatment, the bacteria were immediately transferred to $50^{\circ} \mathrm{C}$. Survival was determined as above.

$\mathrm{H}_{2} \mathrm{O}_{2}$ treatment. Bacteria were grown and suspensions were pipetted into Eppendorf tubes as described above. $\mathrm{CuSO}_{4}$ was added to each tube to a final concentration of $0.1 \mathrm{~mm}$ to increase the rate of hydroxyl radical formation (Brandi et al., 1987; McCord \& Day, 1978). $\mathrm{H}_{2} \mathrm{O}_{2}$ (Mallinckrodt 30\%) was then added to a final concentration of either $4.4 \mathrm{mM}$ or $8.8 \mathrm{mM}$. All tubes were placed on ice for the desired reaction time (reaction temperature was approximately $1.0^{\circ} \mathrm{C}$ ). After a known period of time, one tube was withdrawn from the ice and 2000 units of catalase (Sigma) was added. The bacterial suspension was then serially diluted, immediately plated and incubated as above. Survival was determined as indicated above.

$U V$ treatment. Bacterial cultures grown to about $1 \times 10^{8}$ cells $\mathrm{ml}^{-1}$ were centrifuged at $1000 \mathrm{~g}$ for $20 \mathrm{~min}$, and the cell pellet was resuspended in an equal volume of $\mathrm{M}-9$ salts solution. The suspension was centrifuged, and the cell pellet resuspended again in an equal volume of M-9 salts solution. After standing at room temperature for at least $20 \mathrm{~min} 1 \mathrm{ml}$ samples of the suspension were placed into each of seven small dishes $(35 \times 10 \mathrm{~mm})$, one dish for each time point being studied. The dishes were placed individually under a UV lamp (General Electric) emitting a dose of $1.0 \mathrm{~J} \mathrm{~m}^{-2} \mathrm{~s}^{-1}$, for a specific length of time. After exposure, the dish was removed from the UV light, and the bacteria were serially diluted, plated and incubated as described above. Photoreactivation was avoided, and survival was determined as above.

\section{Results}

Sensitivity of $E$. coli mutants to heat

Repair-defective mutants, $\operatorname{rec} A$ and $\operatorname{rec} A$ uvr $A$, were more sensitive to heat than their wild-type parent (Fig.
$1 a, b)$. These results are in agreement with previous reports (Bridges et al., 1969a,b), and support the conclusion that heat causes DNA damage. Furthermore, the $\operatorname{rec} A$ uvrA double mutant was more sensitive to heat than the $\operatorname{rec} A$ strain. This indicates that both excision and recombinational pathways are employed in the repair of heat-induced DNA damages.

In $E$. coli, the $x t h A$ gene encodes the DNA repair enzyme exonuclease III. $x \operatorname{th} A$ mutants are sensitive to $\mathrm{H}_{2} \mathrm{O}_{2}$, a known DNA-damaging agent (Ames et al., 1985; Demple et al., 1983, 1986). An xthA deletion mutant was also more sensitive to heat than the wild-type (Fig. 1c). This result implies that exonuclease III, the product of the $x t h A$ gene, may be used to repair heatinduced DNA damage.

The DnaK protein is a major heat-shock protein in $E$. coli. As shown in Fig. $1(d)$, the dnaK deletion mutant was very sensitive to heat. This result was previously obtained by Paek \& Walker (1987). The inactivation curves of the wild-type and the $d n a K$ mutant were replotted with best-fit straight lines obtained through linear regression analysis (data not shown). Comparison of the slopes of these curves reveals that the slope of the dnaK inactivation curve is 3.6 times greater than the slope of the wild-type inactivation curve. These results indicate that the $d n a K$ gene is important in protecting $E$. coli from the lethal effect of heat.

\section{Thermotolerance protects against heat-induced damage}

The three mutants $\operatorname{rec} A, \operatorname{rec} A$ uvr $A$ and $x t h A$ with defects in known repair pathways, and wild-type $E$. coli were strongly thermotolerant (Fig. 2). In other words, after heat-shock at $42^{\circ} \mathrm{C}$ for $15 \mathrm{~min}$ there was almost no killing by subsequent treatment at $50^{\circ} \mathrm{C}$, even though they are sensitive to a direct treatment of $50^{\circ} \mathrm{C}$ (compare Fig. $2 a-c$ to Fig. $1 a-c$ ). This suggests that, after establishment of thermotolerance, there is little or no need to repair heat-induced DNA damage by means of repair pathways employing the $\operatorname{rec} A, u v r A$ or $x t h A$ gene products.

In contrast, when the dnaK deletion mutant was also heat-shocked at $42^{\circ} \mathrm{C}$ for $15 \mathrm{~min}$ and then heat-treated at $50{ }^{\circ} \mathrm{C}$, it was killed very rapidly (Fig. $2 d$ ). Comparison of the killing curves of wild-type and the dnaK mutant showed that the slope of the dnaK inactivation curve was 19.6 times greater than the slope of the wild-type inactivation curve. The rate of inactivation of the dnaK mutant at $50^{\circ} \mathrm{C}$ was essentially the same whether pretreated at $42^{\circ} \mathrm{C} \mathrm{(Fig.} 2 d$ ) or not (Fig. 1d).

The dnaK deletion mutant is sensitive to $\mathrm{H}_{2} \mathrm{O}_{2}$

Since the dnaK gene is induced by $\mathrm{H}_{2} \mathrm{O}_{2}$ treatment (VanBogelen et al., 1987), the effect of $\mathrm{H}_{2} \mathrm{O}_{2}$ on the 

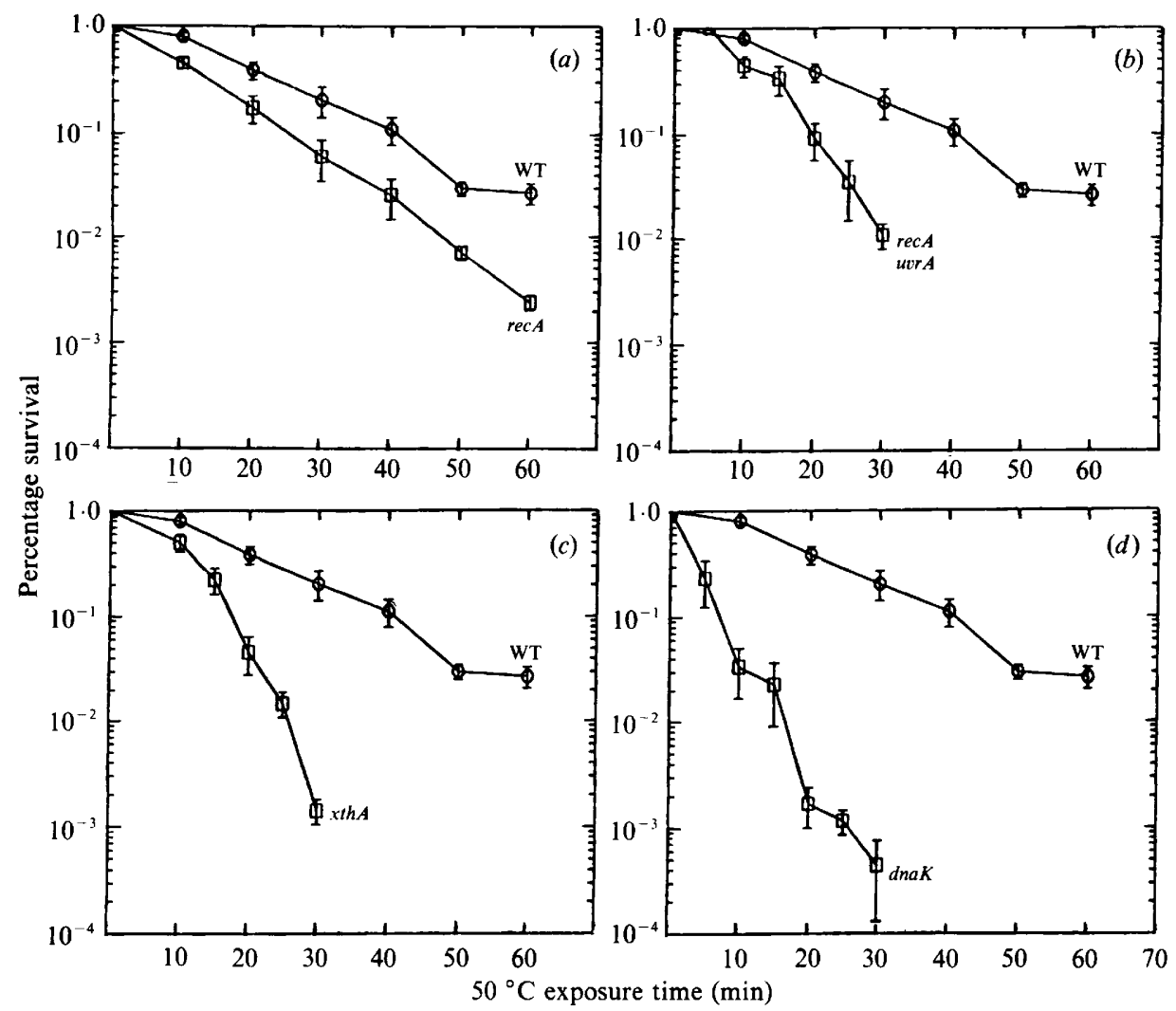

Fig. 1. Sensitivity of $E$. coli strains to a temperature of $50^{\circ} \mathrm{C}$. Each point is a mean value based on determinations from at least three experiments. Error bars indicate standard error of the mean. WT, Wild-type.
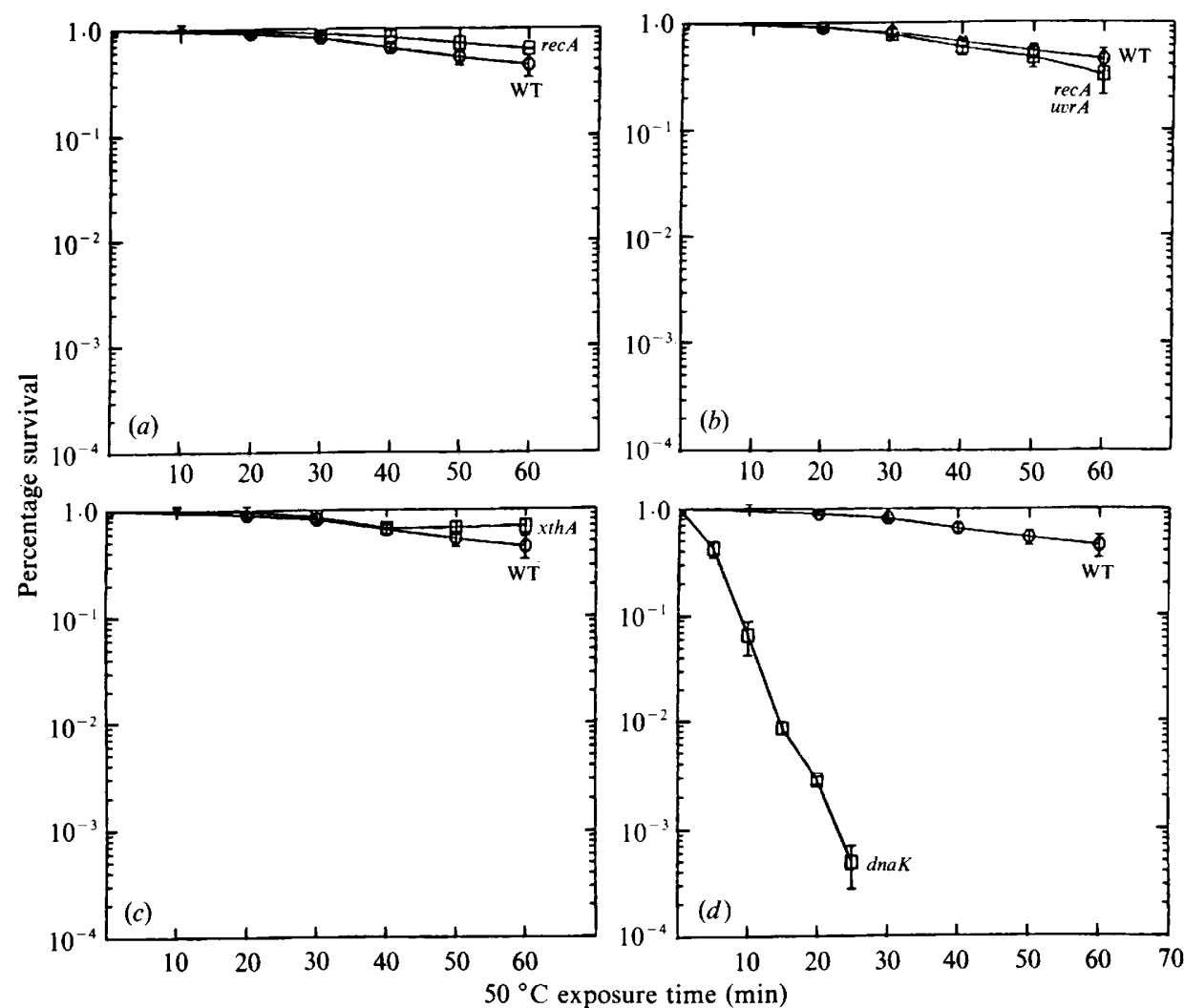

Fig. 2. Sensitivity of $E$. coli strains to a temperature of $50^{\circ} \mathrm{C}$ following exposure at $42^{\circ} \mathrm{C}$ for $15 \mathrm{~min}$. Each point is a mean value based on determinations from at least three experiments. Error bars indicate standard error of the mean. WT, Wild-type. 


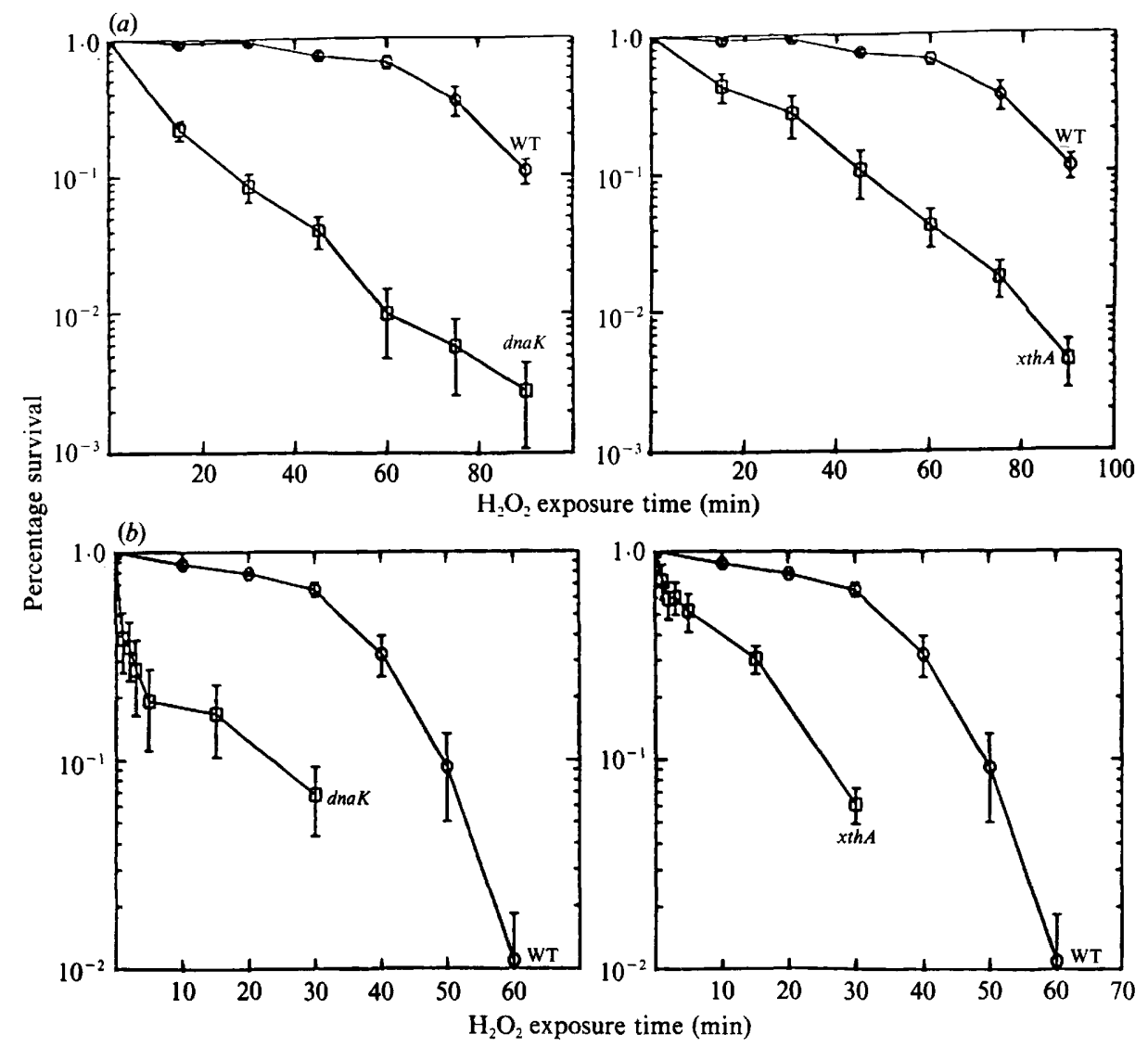

Fig. 3. Sensitivity of $E$. coli strains to exposure to $(a) 4.4 \mathrm{mM}-\mathrm{H}_{2} \mathrm{O}_{2}$ and $(b) 8.8 \mathrm{mM}-\mathrm{H}_{2} \mathrm{O}_{2}$. Each point is a mean value based on determinations from at least three experiments. Error bars indicate standard error of the mean. WT, Wild-type.

survival of the dnaK mutant was studied. An $x t h A$ mutant, previously reported to be sensitive to $\mathrm{H}_{2} \mathrm{O}_{2}$ (Demple et al., 1983) was also tested for comparison (Fig. 3). Both the dnaK and $x$ thA mutants were more sensitive to $4.4 \mathrm{~mm}-\mathrm{H}_{2} \mathrm{O}_{2}$ than the wild-type (Fig. $3 a$ ), which was relatively insensitive to $\mathrm{H}_{2} \mathrm{O}_{2}$ up to $60 \mathrm{~min}$ of exposure. Both the $d n a K$ and $x t h A$ mutants were inactivated by $\mathrm{H}_{2} \mathrm{O}_{2}$ at approximately the same rate. At the higher $\mathrm{H}_{2} \mathrm{O}_{2}$ concentration $(8.8 \mathrm{mM})$, wild-type cells were killed more rapidly (Fig. $3 b$ ). Here, wild-type cells were relatively resistant to $\mathrm{H}_{2} \mathrm{O}_{2}$ until $30 \mathrm{~min}$ of exposure, when survival declined rapidly. The $d n a K$ and $x \operatorname{th} A$ strains were initially much more sensitive to this concentration of $\mathrm{H}_{2} \mathrm{O}_{2}$ than to the lower concentration. Killing was most rapid in the $d n a K$ mutant during the early treatment times, such that only $20 \%$ of the cells survived after $5 \mathrm{~min}$ of exposure (Fig. $3 \mathrm{~b}$ ). For the $x \operatorname{thA}$ mutant, killing was also most rapid during the first $5 \mathrm{~min}$ of treatment. These results indicate that the $d n a K$ gene, like $x$ th $A$, is needed to protect $E$. coli from $\mathrm{H}_{2} \mathrm{O}_{2}$.

$\mathrm{UV}$ irradiation turns on the heat-shock response and induces the $d n a K$ gene (Krueger \& Walker, 1984). To determine if the $d n a K$ gene protects a cell generally or if it is limited to specific types of environmental stress, the effect of UV on the dnaK deletion mutant was studied. Wild-type and $d n a K$ mutant cells were irradiated with up to $180 \mathrm{~J}$ of UV light, a dose which has been shown to induce the $E$. coli heat-shock response (Krueger \& Walker, 1984). The results of these experiments indicated that the dnaK mutant is not more sensitive to UV than the wild-type (data not shown). This implies that the dnaK gene is not involved in protecting cells from UV-induced DNA damage.

\section{Discussion}

Treatment of $E$. coli with a sub-lethal dose of heat results in resistance to subsequent heat exposure, i.e. thermotolerance. This induced heat resistance occurs independently of $\operatorname{rec} A-$, uvrA- or $x t h A$-mediated repair systems, but is absent in a dnaK mutant. These results imply that the development of thermotolerance, an inducible protective mechanism, abrogates the need for the rec $A$, $u v r A$ and $x t h A$ DNA repair pathways. Therefore, another heat-inducible system must exist which eliminates the DNA damaging potential of heat. 
Deletion of the dnaK gene from $E$. coli results in cellular defects at a wide range of temperatures (Bukau \& Walker, 1989). This suggests that the DnaK protein has important cellular functions at both normal and high growth temperatures, and, in fact, the DnaK protein is essential for growth at high temperatures (Bukau \& Walker, 1989; Itikawa \& Ryu, 1979; Paek \& Walker, 1987). In addition, DnaK is necessary for initiation of DNA replication in $E$. coli at high temperatures (Sakakibara, 1988) and in bacteriophage $\lambda$ at all temperatures (Dodson et al., 1986). I have shown that the dnaK mutant is very sensitive to $\mathrm{H}_{2} \mathrm{O}_{2}$. Therefore, the DnaK protein may also function to protect a cell from oxidative stress. Since heat and $\mathrm{H}_{2} \mathrm{O}_{2}$ at the concentration used may cause nucleic acid, protein and membrane damage, any of these may be the targets of DnaK protection.

The dnaK deletion mutant is very sensitive to heat even under conditions in which thermotolerance would otherwise be induced (Fig. $2 d$ ). This suggests that the DnaK protein provides some function which is essential for the development of thermotolerance. The precise nature of this function is not known, but many possibilities exist. E. coli dnaK mutants are deficient in both DNA and RNA synthesis and cell division is blocked at non-permissive temperatures (Bukau \& Walker, 1989; Itikawa \& Ryu, 1979; Massie et al., 1972; Saito \& Uchida, 1977). Therefore, DNA and/or RNA synthesis may be required for the development of thermotolerance in a dnaK deletion mutant. Since the DnaK protein inhibits the heat-shock response in $E$. coli (Tilly et al., 1983), another possibility is that DnaK provides some type of regulatory function for the development of thermotolerance which is missing in the dnaK deletion mutant. Alternatively, the DnaK protein may be required for replication or repair of DNA at high temperatures.

Spontaneous DNA damage due to heat or oxidative processes appears to be a serious problem with which organisms must cope (Ames et al., 1985; Setlow, 1987). One function of the E. coli heat-shock response could be to specifically repair the type of DNA damage caused by heat and $\mathrm{H}_{2} \mathrm{O}_{2}$. The heat-shock response may be well suited to repair the DNA damage induced by both heat and oxidative reactions because these damages are similar. Both heat and $\mathrm{H}_{2} \mathrm{O}_{2}$ cause base alterations which result in apurinic and apyrimidinic (AP) sites (Hagensee \& Moses, 1986; Massie et al., 1972; Ripley, 1988). Maintenance of the replicative integrity of DNA at high temperatures would allow a cell to survive heat stress more efficiently than a cell without such a process, and might result in the high degree of conservation seen in the heat-shock response.
I am very grateful to Barbara Bachmann and Graham Walker for supplying the bacterial strains used in this study. I would also like to thank Harris Bernstein and John Spizizen for their many helpful discussions and for critical review of this manuscript. This work was supported by NIH grant GM27219-08 to Harris Bernstein.

\section{References}

ADAms, M. H. (1959). Bacteriophages. New York: Interscience.

ames, B., Saul, N., Schwiers, E., Adelman, R. \& Cathcart, R. (1985). Oxidative DNA damage as related to cancer and aging: assay of thymine glycol, thymidine glycol, and hydroxymethyluracil in human and rat urine. In Molecular Biology of Aging: Gene Stability and Gene Expression, p. 137. Edited by R. S. Sohoal. New York: Raven Press.

ANANTHASWAMY, H. N. \& EISENSTARK, A. (1977). Repair of hydrogen peroxide-induced single strand breaks in Escherichia coli deoxyribonucleic acid. Journal of Bacteriology 130, 187-191.

Brandi, G., Sestili, P., Pedrini, M. A., Salvaggio, L., Cattabeni, F. \& CANTONI, O. (1987). The effect of temperature or anoxia on Escherichia coli killing induced by hydrogen peroxide. Mutation Research 190, 237-240.

BRIDGes, B. A., AshWOOD-SMith, M. J. \& Munson, R. J. (1969a). Correlation of bacterial sensitivities to ionizing radiation and mild heating. Journal of General Microbiology 58, 115-124.

Bridges, B. A., Ashwood-Smith, M. J. \& Munson, R. J. (1969b). Susceptibility of mild thermal and of ionizing radiation damage to the same recovery mechanisms in Escherichia coli. Biochemical and Biophysical Research Communications 35, 193-196.

BUKAU, B. \& WALKER, G. C. (1989). Cellular defects caused by deletion of the Escherichia coli dnaK gene indicate roles for heat shock proteins in normal metabolism. Journal of Bacteriology 171, 2337-2346.

Demple, B., HalBRock, J. \& LinN, S. (1983). Escherichia coli xth mutants are hypersensitive to hydrogen peroxide. Journal of Bacteriology 153, 1079-1082.

Demple, B., Johnson, A. \& Fung, D. (1986). Exonuclease III and endonuclease IV remove 3 ' blocks from DNA synthesis primers in $\mathrm{H}_{2} \mathrm{O}_{2}$ damaged Escherichia coli. Proceedings of the National Academy of Sciences of the United States of America 83, 7731-7735.

Dodson, M., Echols, H., Wickner, S., Alfano, C., Mensa-Wilmot, K., Gomes, H., LeBowitz, J., RoberTs, J. D. \& MCMaCKeN, R. (1986). Specialized nucleo-protein structures at the origin of replication of bacteriophage $\lambda$ : localized unwinding of duplex DNA by a six-protein reaction. Proceedings of the National Academy of Sciences of the United States of America 83, 7638-7642.

HAGENSEE, M. E. \& MOSES, R. E. (1986). Repair response of Escherichia coli to hydrogen peroxide DNA damage. Journal of Bacteriology 168 , 1059-1065.

Howard-Flanders, P. \& Theriot, L. (1966). Mutants of Escherichia coli $\mathrm{K}-12$ defective in DNA repair and in genetic recombination. Genetics 53, 1137-1150.

Howard-Flanders, P., Theriot, L. \& STedford, J. B. (1969). Some properties of excision-defective recombination-deficient mutants of Escherichia coli K-12. Journal of Bacteriology 97, 1134-1141.

ITIKAWA, H. \& RYU, J.-I. (1979). Isolation and characterization of a temperature-sensitive dnaK mutant of Escherichia coli B. Journal of Bacteriology 138, 339-344.

KRUEGER, J. H. \& WALKER, G. C. (1984). groEL and $d n a K$ genes of Escherichia coli are induced by UV irradiation and nalidixic acid in an $h t p R^{+}$-dependent fashion. Proceedings of the National Academy of Sciences of the United States of America 81, 1499-1503.

LINDQUIST, S. (1986). The heat shock response. Annual Review of Biochemistry 55, 1151-1191.

Massie, H. R., Somis, H. V. \& Baird, M. B. (1972). The kinetics of degradation of DNA and RNA by $\mathrm{H}_{2} \mathrm{O}_{2}$. Biochimica et Biophysica Acta 272, 539-548. 
McCord, J. M. \& DAY, D. D. (1978). Superoxide-dependent production of hydroxyl radical catalyzed by iron-EDTA complex. FEBS Letters 86, 139-142.

NeidhardT, F. C., VanBogelen, R. A. \& Vaughn, V. (1984). The genetics and regulation of the heat-shock proteins. Annual Review of Genetics 18, 295-329.

PAEK, H.-H. \& W ALKER, G. (1987). Escherichia coli dnaK null mutants are inviable at high temperature. Journal of Bacteriology 169, 283-290.

RIPLEY, L. S. (1988). Estimation of in vivo miscoding rates. Journal of Bacteriology 202, 17-34.

SaITO, H. \& UCHIDA, H. (1977). Initiation of the DNA replication of bacteriophage lambda in Escherichia coli K-12. Molecular and General Genetics 164, 1-8.

Sakakibara, Y. (1988). The dnaK gene of Escherichia coli functions in initiation of chromosome replication. Journal of Bacteriology 170, 972-979.

SChlesinger, M. J., Ashburner, M. \& Tissieres, A. (1982). Heat Shock from Bacteria to Man. Cold Spring Harbor, New York: Cold Spring Harbor Laboratory.

SETLOw, B. B. (1987). Theory presentation and background summary. In Modern Biological Theories of Aging, p. 177. Edited by H. R. Warner. New York: Raven Press.
Steinberg, C. M. \& Edgar, R. S. (1962). A critical test of a current theory of genetic recombination in bacteriophage. Genetics 47, $187-208$.

Subjeck, J. R. \& Sciandra, J. J. (1982). Coexpression of thermotolerance and heat shock proteins in mammalian cells. In Heat Shock from Bacteria to Man, pp. 405-411. Edited by M. J. Schlesinger, M. Ashburner \& A. Tissieres. Cold Spring Harbor, New York : Cold Spring Harbor Laboratory.

Tilly, K., McKitTRICK, N., Zylicz, M. \& Georgopoulos, C. (1983). The dnaK protein modulates the heat-shock response of Escherichia coli. Cell 34, 641-646.

VanBogelen, R. A., Kelly, P. M. \& Neidhardt, F. C. (1987) Differential induction of heat shock, SOS, and oxidation stress regulons and accumulation of nucleotides in Escherichia coli. Journal of Bacteriology 169, 26-32.

WoODCOCK, E. \& GRIGG, G. W. (1972). Repair of thermally induced DNA breakage in Escherichia coli. Nature New Biology 237, 76-79.

YAMAMORI, T. \& YURA, T. (1982). Genetic control of heat-shock protein synthesis and its bearing on growth and thermal resistance in Escherichia coli K-12. Proceedings of the National Academy of Sciences of the United States of America 79, 860-864. 